\title{
How Non-Majoritarian Institutions Make Silent Majorities Vocal: A Political Explanation of Authoritarian Populism
}

\author{
Michael Zürn
}

\begin{abstract}
Why did we witness such a strong growth of anti-liberal forces twenty-five years after the triumph of liberalism? The answer is twofold. First, authoritarian populism has not sneaked into a given political space but is co-constitutive of a new cleavage in most modern societies. Authoritarian populists speak to the issues of this cleavage. Second, the rise of this new cleavage and authoritarian populists cannot be reduced to one of the two well-known explanations, namely the economic insecurity perspective and cultural backlash perspective. This current paper develops a political explanation that integrates struggles over policies with a focus on endogenous dynamics of political institutions in and beyond democracies. In this account, it is the historical compromise between labor and capital that has triggered a dynamic in which the rise of so-called non-majoritarian institutions (NMIs)—such as central banks, constitutional courts, and international organizations (IOs) — have locked in liberal policies in most consolidated democracies. This explanation brings together the party cartelization thesis with the observation that NMIs are a major target of contemporary populism. The explanatory model is probed by translating it into descriptive propositions and by showing step by step how the sequence unfolded in electoral democracies.
\end{abstract}

n 2018, populist parties like Geert Wilders' Party for Freedom (Partij voor de Vrijheid, PVV) received an average of $22.2 \%$ of the vote in thirty-three European countries (Timbro Populism Index 2019). While authoritarian populists are thus far beneath a majority of the vote in most societies, some of them have even made it into

A list of permanent links to Supplemental Materials provided by the authors precedes the References section.

Data replication sets are available in Harvard Dataverse at: https:/ldoi.org/10.7910/DVN/7BCD4I.

\section{Michael Zürn (1) is Director of the Global Governance unit at WZB Berlin Social Science Center and Professor of Inter- national Relations at Freie Universität Berlin (michael. zuern@wzb.eu). He is director of the DFG-funded Cluster of Excellence "Contestations of the Liberal Script" (SCRIPTS) and member of the Berlin-Brandenburg Academy of Sciences and Humanities as well as the Academia Europaea. Previ- ously, he served as Founding Dean of the Hertie School. His work focuses on the emergence and functioning of inter-and supranational institutions and organizations and their impact on political orders. A Theory of Global Governance was published by Oxford University Press, 2018.}

government in consolidated democracies either as chief executives by capturing a mainstream party (mostly in majority voting systems, as in the United States) or as part of a coalition government where no party can govern on their own (mostly in proportional voting systems as in Italy). Outside the group of consolidated democracies, they are even more successful. In some large countries like India, Brazil, or Turkey, as well as in some Eastern European countries, they are in power, and they still maintain elections that are open to opposition parties. In any case, populists claim to act in the name of the people and display significant electoral support.

Concurrently, all the populists mentioned have an authoritarian bend and "negativist" approach (Urbinati 2019, 22). They are "anti-pluralist" in the sense that they often hold a de-proceduralized and homogeneous notion of "the silent majority." They are "anti-liberal" in the sense that they question individual and especially minority rights. Authoritarian populists also are "anti-internationalist," since they unconditionally support national sovereignty and reject any political authority beyond the nation-state. These negativist positions are bound together by pitting the "people" against a "corrupt cosmopolitan elite" that belies the natives. Authoritarian populists challenge liberal orders (Levitsky and Ziblatt 2018). Liberal orders contain commitments to individual rights, the rule of law, democracy, and relatively permits unrestricted re-use, distribution, and reproduction in any medium, provided the original work is properly cited. 
open borders (for a discussion of the liberal international order, cf. Lake, Martin, and Risse 2021).

Authoritarian populists are a worldwide phenomenon, and, in most electoral democracies, there is at least one strong authoritarian populist party in the parliament. Why do we witness such a strong growth of anti-liberal forces twenty-five years after the triumph of liberalism that came with the fall of the Berlin Wall? The answer has two components. First, authoritarian populism is put into context; it has not sneaked into a given political space but is co-constitutive of a new cleavage in most modern societies. Second, the argument is introduced that the rise of this new cleavage and authoritarian populists cannot be reduced to one of the two well-known competing explanations (Norris and Inglehart 2019; Przeworski 2019, ch. 6). The economic insecurity perspective explains it by focusing on the distributive consequences of economic globalization and post-industrial transformation. The cultural backlash perspective suggests that authoritarian populism is the result of a retro action against the value change indicated by terms like post-materialism, feminism, and multi-culturalism. Both of these explanations capture key aspects, but they seem to ignore the underlying politics.

Therefore, a political explanation is developed that integrates struggles over policies with a focus on the endogenous dynamics of political institutions during recent decades. Accordingly, the historical compromise between labor and capital has triggered a dynamic, at the end of which the rise of so-called non-majoritarian institutions (NMIs) — such as central banks, constitutional courts, and international organizations (IOs) - have locked in liberal policies in most democracies. This explanation brings together the party cartelization thesis (Mair 2013) to observe that NMIs constitute a significant target of contemporary populism (Mounk 2018). The gap between representatives in parliaments and voters grew. Moreover, NMIs often outweigh parliamentary decisions. Consequently, the silent majority consider themselves as suppressed or at least forgotten by a political class controlling the parliament and by liberal cosmopolitan experts controlling NMIs. Therefore, authoritarian populists pit the notion of the silent majority against the political classes and NMIs.

The article proceeds in three steps. I first define authoritarian populism and put it in the context of cleavage theory. Next I develop a historical-institutionalist account of the theoretical narrative about the institutional dynamics. I then probe this explanatory model by translating it into descriptive propositions. This shows step by step how the sequence unfolds and then relates it to alternative explanations.

\section{The Rise of Authoritarian Populism as One Side in a New Cleavage}

The dominant approach to study contemporary populism is the ideational one. In this view, populism is "defined as a set of ideas that not only depicts society as divided between the 'pure people' versus the 'corrupt elite,' but also claims that politics is about respecting popular sovereignty at any cost" (Mudde 2004, 542). Accordingly, the emphasis on anti-elitism and popular sovereignty is a thin ideology, i.e., a specific set of ideas that is distinct from thick ideologies_-such as liberalism-because it has limited programmatic scope (Freeden 2003).

While I follow the ideational approach and consider populism as more than just a political strategy of leaders independent of their underlying political vision (Weyland 2017), "authoritarian populism" is considered to be a full ideology. From a cleavage perspective (Lipset and Rokkan 1967; Mair 2005), no ideology speaks to all potential issues, but it responds to the urgent problems of a given era. In this perspective, ideologies only develop in interaction with competing ones and bind together the topics relevant for a given cleavage. Such an ideology does not depend on sophisticated philosophical texts but on the "capacity to fuse ideas and sentiments" to "create public justifications for the exercise of power" (Müller 2011, 92). The anti-liberalism, anti-internationalism, anti-pluralism, and anti-elitism of authoritarian populism connects to the relevant issues of the new cleavage by privileging closed borders and the will of the majority, as well as by rejecting authority beyond the nation-state.

Authoritarian populism, in this view, is thicker than just the thin ideology of juxtaposing the establishment against the people-it also contains a notion of rule that replaces representative democracy by a "supposedly direct representation between the people and the leader" (Urbinati $2019,7)$. The empowering of "the people" translates into a demand for delegating the power to the leader(s) of the populist party. An election poster for Heinz-Christian Strache, once the leader of the Freedom Party of Austria (Freiheitliche Partei Österreichs, FPÖ), unmistakably stated "HE wants, what WE want" ("ER will, was WIR wollen"; cited in Müller 2016, 47). Authoritarian populism thus contains a particular form of anti-elitism that is better described as counter-elitism. What still appears to be democratic in opposition may turn out to be authoritarian in power. In authoritarian populism, the volonté générale plays out as a pre-political and de-proceduralized will that is embodied in the leaders of the populist party (Urbinati 2019; Weyland 2017).

Authoritarian populism can be defined as a political ideology that is majoritarian and nationalist (Caramani 2017). It is majoritarian by pitting a majority's homogenous will against liberal rights, tolerance, and pluralist willformation. It is nationalist by pitting the significance of borders and the national will against an open world society with influential international institutions. These beliefs are bundled in constructing a firm antagonism between corrupt and distant cosmopolitan elites and the decent and local people. 
Authoritarian populism has quickly spread around the world of electoral democracies. In some political systems, other new parties have become stronger as well. Emmanuel Macron's The Republic on the Move (La République En Marche!) in France and the Coalition of the Radical Left (Syriza) in Greece are well known examples. These parties challenged and replaced old parties without showing antiliberalism, anti-pluralism, or anti-internationalism. They are better described as challenger parties (De Vries and Hobolt 2020). However, it is mainly authoritarian populist parties — and, to a lesser extent, green parties - that became significantly stronger across most electoral democracies since the 1980s (see Armingeon et al. 2020; Benedetto, Hix, and Mastrorocco 2020).

How can we explain the rise of authoritarian populism? First of all, the rise of authoritarian populism is anchored in a new contradiction in line with cleavage theory. Cleavages point to social revolutions that create sociostructural divisions. In the case of the new cleavage, the underlying social revolution is globalization. The social changes triggered by globalization and Europeanization are regarded as decisive by most analysts of the new cleavage (Marks and Wilson 2000; Kriesi et al. 2012; De Wilde et al. 2019). Yet when it comes to the causal mechanism via which globalization has produced a new cleavage, two competing accounts can be distinguished. These two accounts are also prevalent when the causes of authoritarian populism are studied without the cleavage framework (see Inglehart and Norris 2017; Norris and Inglehart 2019; Mudde and Kaltwasser 2012).

On one hand, the economic insecurity perspective emphasizes the distributive consequences of economic globalization and post-industrial transformation. It is then growing inequality, the rise of precarious working situations, and a gap between labor productivity and real wage index in advanced economies that led to the growth of authoritarian populism (Hobolt 2016; Manow 2018; Przeworski 2019; Flaherty and Rogowski 2021). The economic explanation also points to the new grievance between thriving cities and declining regions (Broz, Frieden, and Weymouth 2021). On the other hand, the cultural backlash perspective suggests that authoritarian populism results from a reaction against the post-material value change (Fukuyama 2018; Hochschild 2016). Both of these explanations highlight a relevant part of the current dynamics and explain variations, still leaving challenging questions unanswered.

The socio-economic explanation raises two particular questions. The first one is about the relationship between the losers of globalization and the political program of authoritarian populists. Why do the losers of globalization support authoritarian populists instead of parties of the new left, who often promise social protection more clearly? The second is about the countries where authoritarian populism is strong. Why is there little variation in the strength of authoritarian populism between Scandinavian countries with much less inequality and Anglo-Saxon countries with much more accentuated economic inequality (Milanovic 2016)?2 If we include authoritarian populism in more precarious democracies, another question arises: Why have authoritarian populists achieved electoral victories and have held power in societies with very dynamic economies over recent decades, such as Turkey and Poland? While these societies are familiar with globalization losers, their share can be expected to be smaller than in Western Europe or the United States.

Similarly, the socio-cultural explanation of authoritarianism leaves essential questions unaddressed. First of all, there is a particular danger that this explanation conflates cause and effect since cultural struggles only intensify after the rise of populist parties (Manow 2018). Moreover, if we see a cultural backlash, why are European and international institutions, such as the European Union (EU) and the International Monetary Fund (IMF), a target of all authoritarian populists even though neither of them is the spearhead of post-material thinking? When looking at more precarious democracies, the question is why authoritarian populism is especially strong in countries such as Russia and Turkey, where the value change has been much less far-reaching than in Anglo-Saxon or Scandinavian countries.

To answer these questions, we offer a political explanation that can integrate the economic and cultural explanation. It is necessary to complement the existing accounts of authoritarian populism with a political explanation that points to the path-dependent effects of certain institutional decisions taken at historical junctures after World War II. Accordingly, the cartelization of party politics that started after World War II (Dahl 1965; Kriesi 2014; Mair 2013; Benedetto, Hix, and Mastrorocco 2020) has led to a decline of trust in parties and democracies from the 1960s on. The ensuing rise of NMIs on the national and international level from the early 1980s on has locked in policies that are in line with liberal cosmopolitan thinking. Together, these two developments have decreased the responsiveness of political institutions and the perception that they are beyond the reach of the silent majority. It is this perception that is decisive for the rise of authoritarian populism. It is not the unfavorable policies alone that cause dissatisfaction, but the feeling that these policies cannot be changed within the "old system." In the words of Nadia Urbinati, the confidence that "no majority is the last one" (2019, 91) gets lost. The full explanation applies only to authoritarian populists in consolidated democracies. Yet the emergent silent-majority narrative has diffused to more precarious democracies in Eastern Europe and some of the rising powers. In these countries, the nationalist sentiment emphasizes the will of the silent majority against its usurpation by liberal cosmopolitan 
leaders within the country and the EU as well as international financial institutions.

This explanation displays some genealogical depth while remaining sufficiently parsimonious to be generalizable across countries. The composite mechanism consists of a thick sequence or a chain of events, connecting potentially distant independent and dependent variables. In this case, the composite mechanism postulates a connection between the historical compromise and the rise of authoritarian populism.

How can such an explanation be explored? As a first step, a theoretical narrative is developed that consists of a historical sequence. In such a narrative, the macrocomponents need to be proximate enough to become intuitively compelling (Mahoney 2012, 581). The micro-links that connect the macro-components must be theoretically sound by relying on a generalizable relationship. Most qualitative analyses build implicitly on such a notion by providing an "analytical narrative" (Büthe 2002). As a second step, the theoretical narrative is probed. For this purpose, the theoretical narrative is translated into four descriptive propositions that bind the steps to a specified timeline and the causal mechanism and alternative explanations are discussed.

\section{The Analytical Narrative}

According to a World Value Survey (WVS), over 85\% of the people want to be governed by a "democratic political system" (Inglehart et al. 2014). A closer look, however, reveals that many of those have little confidence in parliaments and parties but prefer institutions that do not depend on majorities. 3 "This "democratic paradox" is grounded in the dynamic relationship between majoritarian institutions (MIs) and NMIs in democratic political systems.

Parliaments and parties play a crucial role in representative democratic political systems (Dahl 1989). Parliaments decide by a majority of elected representatives. The representatives, in turn, are elected in free and equal elections based on a competition between parties. Parliaments and parties thus are MIs embodying the idea of popular sovereignty. Both institutions are accountable to the individual members of society. Each decision, at least in principle, can be reversed if a new majority arises. Since everyone has the opportunity to raise their voice, the decisions taken by MIs reflect the views of the majority.

Non-majoritarian institutions, such as courts and central banks, have always played an indispensable role in democratic political systems. In democratic theory, the primary task of NMIs is to control and limit the public powers so that they do not violate individual and minority rights or undermine the democratic process (Elster 1994). Besides, they need to implement the norms set by the legislative branch (Ackerman 2000). International institutions can also be seen as NMIs since they can protect democracy and human rights and help to implement agreed-upon political goals (Keohane, Macedo, and Moravcsik 2009). NMIs are often nominated by majoritarian political bodies to exercise authority. While these appointments can be politically contested along party linesUnited States Supreme Court nominations are the bestknown examples-the members of an NMI exercise epistemic authority after they are nominated. Their decisions rely on the idea that they know better, and not on the notion of a majority of representatives. Even if an NMI decides internally via a majority vote, neither the body nor the individual members are accountable to the individuals within a given society. NMIs or "counter-majoritarian institutions" (Rosanvallon 2008) can be defined as governance entities that a) possess and exercise specialized public authority separate from that of other institutions, $b$ ) are neither directly elected by the people nor managed by elected officials, and instead c) refer to the epistemic quality in justifying the decision (see, similarly, Thatcher and Stone Sweet 2002, 2).

In a constitutionalist conception of democratic rule, parliaments are the norm setters and, together with the executive, they stand for the foundational component. On the contrary, NMIs play a limitational role (Krisch 2010). In recent decades, however, specialized authorities have risen in quantity and quality so that they nowadays play a limitational and a foundational role. The power shift in favor of NMIs and their policies, in turn, is the outcome of a political process that can be labeled the cartelization of the party systems in consolidated democracies. Both processes have decreased the responsiveness of democratic political systems to the needs of the so-called "silent" or "native" majority. This historical-institutionalist explanation of authoritarian populism consists of a causal sequence of four steps that produced the democratic paradox.

First, the political dynamic that shifted the relationship between MIs and NMIs has been triggered by a historical compromise at $t_{1}$. The compromise consisted of three elements: embedded liberalism, the new arrangement between capital and labor, and the subsequent rise of catch-all parties. After World War II, embedded liberalism was established under United States leadership at a critical juncture. The so-called Bretton Woods Institutions and the General Agreement on Tariffs and Trade (GATT) were crucial for the setup. They institutionalized free trade but also allowed for a national welfare state absorbing economic shocks and uncertainties (Ruggie 1982). Embedded liberalism depended on and allowed for the institutionalization of a new deal in almost all Western democracies, by which capital and labor developed an historic compromise. Unions accepted open borders and ensuing economic insecurities, while the export-oriented business associations accepted the building-up of the welfare state to buffer these uncertainties. This compromise came in 
different versions. It started with Franklin D. Roosevelt's New Deal in the United States in the 1930s, and continued with Scandinavian small states in the world market immediately after World War II (Katzenstein 1985). The conservative welfare states in Europe followed from the 1950s on (Esping-Andersen 1990).

The arrangement was successful. It allowed for the consolidation of democracies in Western Europe. Yet it also led to a change in the party landscape. A new type of party emerged for which Otto Kirchheimer coined the term "catch-all party" (Kirchheimer 1965). A catch-all party is a political party that aims to attract people with diverse political viewpoints, appealing to broad segments of the electorate, and thus moving to the political center (Downs 1957). Party systems dominated by two catch-all parties emerged in most Western European countries: a social-democratic one on the left and a liberal-conservative one on the right. In parallel, the New Deal restructured the party system in the United States presidential system along similar lines.

Consequently, most parties weakened their class orientation and strengthened their leadership. First, the difference between the left and the right diminished. Especially the programmatic differences on classical socio-economic issues decreased. Catch-all parties moved to the center, thus becoming more pragmatic. This, in turn, led to problems of internal discipline, as more traditionally oriented party members and parliamentary representatives challenge some of the policy directions. As a response, the centralization and strengthening of the party leadership took place. The rise of catch-all parties led to the abandonment of ideological positions and traditional class orientations on the most important parties, the strengthening of their leadership, and a very close association between ruling parties and the interest groups of capital and labor. In some countries, a closed system called "corporatism" emerged (Lehmbruch 1977).

That the rise of catch-all parties could cause problems was already foreseen by Robert Dahl in the 1960s. In Dahl's view, catch-all parties came with the

politics of compromise, adjustment, negotiation, bargaining; a politics carried on among professional and quasi-professional leaders who constitute only a small part of the total citizen body; a politics that reflects a commitment to the virtues of pragmatism, moderation and incremental change; a politics that is un-ideological and even anti-ideological ... [Many citizens see this form of politics] as too remote and bureaucratized, too addicted to bargaining and compromise, [and] too much an instrument of political elites and technicians. (1965, 21-22)

The heyday of catch-all parties was in between the late 1950 s and the early 1970s. At this timepoint $1\left(t_{1}\right)$, a political dynamic emerged that led in $t_{2}$ to the decline in trust in parties and parliaments. Thus the first proposition is that the rise of catch-all parties led to a growing alienation between members and voters of a party and their parliament representatives. The effects of this change are strongest for social democratic parties (Benedetto, Hix, and Mastrorocco 2020).

P1: After the rise of catch-all parties, a decline of trust in the majoritarian institutions of electoral democracies started in the $1960 \mathrm{~s}$ and $1970 \mathrm{~s}\left(\mathrm{t}_{2}\right)$.

In the next step, this development translated into a growing relevance of NMIs in $t_{3}$. Increasingly, NMIs not only double-checked and implemented decisions of MIs, but they also became vital in policy making and norm setting. In the domestic realm, independent central banks worldwide became more autonomous and-given the shift to supply-side policies-more critical at the same time (Cukierman 2008). Similarly, the increase in the importance of constitutional courts took place in many countries (Hirschl 2004). In addition to these domestic developments, a dense network of international arrangements and organizations that differ in both quality and quantity from traditional international institutions has developed (Hooghe, Lenz, and Marks 2019). The new international institutions exercise authority over their constituent members while intervening profoundly in the internal affairs of countries.

The rise of domestic and international NMIs was due to two developments. On one hand, the declining trust in parties that started in the 1960s required compensation through the empowerment of trustworthy institutions. Simultaneously, the juxtaposition of two political camps created a common interest to constrain the opponent when out of power (Stone Sweet and Mathews 2019, 18). In this situation, majoritarian decisionmakers are more likely to transfer competencies to trusted institutions to balance and increase legitimacy at the same time. Constitutional courts, central banks, and other NMIs indeed were, for a long time, considered as much more trustworthy than parties and parliaments. International institutions also received remarkable support rates (Hay 2007, 34). Therefore, balancing and legitimacy seeking is one micro-mechanism connecting the decline of trust in MIs with the rise of NMIs. This includes a dose of "blame shifting." There was an increased need to find institutions that can be made responsible for those decisions that are the outcome of compromise and moderation within the political realm but are not necessarily very popular with the party members and voters. Whereas blame shifting is a permanent tool of skillful politicians in modern democracies (Whittington 2005), it moved to the institutional level when the politics of compromise and moderation was tough to sell to all of voters of catch-all parties.

On the other hand, the opening of markets created more intensive competition for foreign investments and a need for signaling reliability. NMIs send a signal to international investors that the rule of law and economic reason protects investments in the long run. The shift towards NMIs was, therefore, accelerated by the globalization thrust starting in 
the 1980s and by accompanying neoliberal policies. The competition for investments increased the value of institutionalized commitments, and it further increased the need for blame shifting on the side of decision makers in MIs (Cerny 1995; Slobodian 2018).

In general, the transfer of decision-making powers to NMIs is part of what Bergman and Strøm called the "Madisonian turn" in their study of Nordic democracies (Bergman and Strøm 2011), and Müller the "euthanasia of politics" (Müller 2011, 143). This turn started when trust in parties and parliaments decreased and accelerated when globalization set in. ${ }^{4}$

P2: The 1980s and 1990s $\left(\mathrm{t}_{3}\right)$ saw a rise of non-majoritarian institutions in electoral democracies.

In our times, non-majoritarian institutions have, on average, a cosmopolitan bias. Courts emphasize and defend individual rights on the constitutional level, often against political majority decisions. Central banks control inflation, thus working in favor of (neoliberal) supply-side policies, sometimes against the welfare preferences of the majority. Regional and international institutions emphasize the need for compliance with international regulations. Also, they often ask for additional authority for IOs. While all NMIs justify their policies on epistemic grounds, they are not politically neutral regarding the new cleavage. There is an elective affinity between NMIs and liberal and cosmopolitan reasoning. ${ }^{5}$ Nevertheless, NMI decision makers are, if at all, only accountable to other parts of the political elites.

In $\mathrm{t}_{4}$, NMIs institutionalize the cosmopolitan political project by locking in certain policies. This dynamic undermined the historic compromise between capital and labor and led to a new constellation from the 1980s on-which looks like a victory for mobile capital.

It took some time before this transformation became visible. In the 1990s, some of the NMIs associated with the Washington Consensus became more visible, such as the IMF, the World Trade Organization, and central banks. The crises of the 2000s added to this. They were revealing moments in which the new power constellations become especially perceptible. The management of the European debt crisis created the impression that it is more important to rescue the banks than to help the poor. At the same time, the central decisions were taken in Brussels but not in national parliaments. Among others, the influx of refugees and Chancellor Angela Merkel's decision to open borders to put pressure away from Greece and Italy and rescue the Eurozone pointed in the same direction.

P3: Non-majoritarian institutions are with increased visibility controlled by actors who lean towards liberal cosmopolitanism from the 1990s $\left(t_{4}\right)$ on.

These developments have accentuated the division between masses and elites on issues like borders, authority transfer, and individual rights. The initial legitimacy benefits of transferring competences to NMIs then lead to additional legitimacy problems. The more authority is delegated to NMIs, and the longer blame is shifted, the more politicized NMIs become (Zürn 2019). They begin to lose trust and support as well. As a result, the disappointment of people about catch-all parties is topped by the frustration with NMIs. They are increasingly seen as instruments of liberal cosmopolitans and the enemies of the "pure people" and the parties that stand for the ideas of the silent majority. As the endpoint of a double process of disappointment-first with traditional parties, then with the initially trusted NMIspeople with less cosmopolitan orientations do not feel represented any longer; they perceive a lack of responsiveness by the political system as a whole.

While a majority still considers democracy as desirable, the trust into democratic institutions further decreases. In this predicament, the appeal to the silent majorities becomes attractive since they feel excluded and deprived of their voice. It is the moment of a revival of MIs and the rise of authoritarian populism.

P4: Especially in the past decade $\left(t_{5}\right)$, the rise of non-majoritarian institutions has produced a rise of authoritarian populist parties.

The proposed explanation of authoritarian populism evinces a sequence of developments. Rather than isolating bivariate relationships, such an explanation refers to "recurrent processes linking specified initial conditions to a specific outcome" (Mayntz 2004, 24). While the idea of a recurrent process is rooted in the idea of "laws" and generalizable micro-mechanisms, the specific connection of different chain links pushes it toward a historically contextualized explanation. ${ }^{6}$ The explanatory model thus includes both recurrent sequences of events ("composite mechanisms") that put relationships between social facts in a broader context and "link mechanisms" that describe the social choices leading from one macro phenomenon to the next (Bunge 1997; Elster 1989; Goertz 2017). This theoretical narrative is summarized in figure 1 . It consists of five composite steps $\left(t_{1}-t_{5}\right)$ and four micro-mechanisms (arrows a-d). It is a fully endogenous mechanism since the outcome does not depend on specific external shocks.

The model can be considered a historicalinstitutionalist one. It is an explanation "that is sensitive to temporality and sequencing, that facilitates causal inference across an unfolding process, and does not prioritize estimation of a single causal effect over other more cumulative contributions to knowledge" (Bateman and Teele 2020, 257). We capture this explanation in a directed acyclic graph (DAG). Each node of the DAG points to a generalizable relationship that is not deterministic and allows for choices. Except for the historical compromise at $t_{1}$, the nodes are no critical junctures; they are seen in most of the historical-institutionalist accounts (Mahoney 2012) as entirely contingent. 


\section{Figure 1}

\section{The historic compromise and the rise of authoritarian populism}

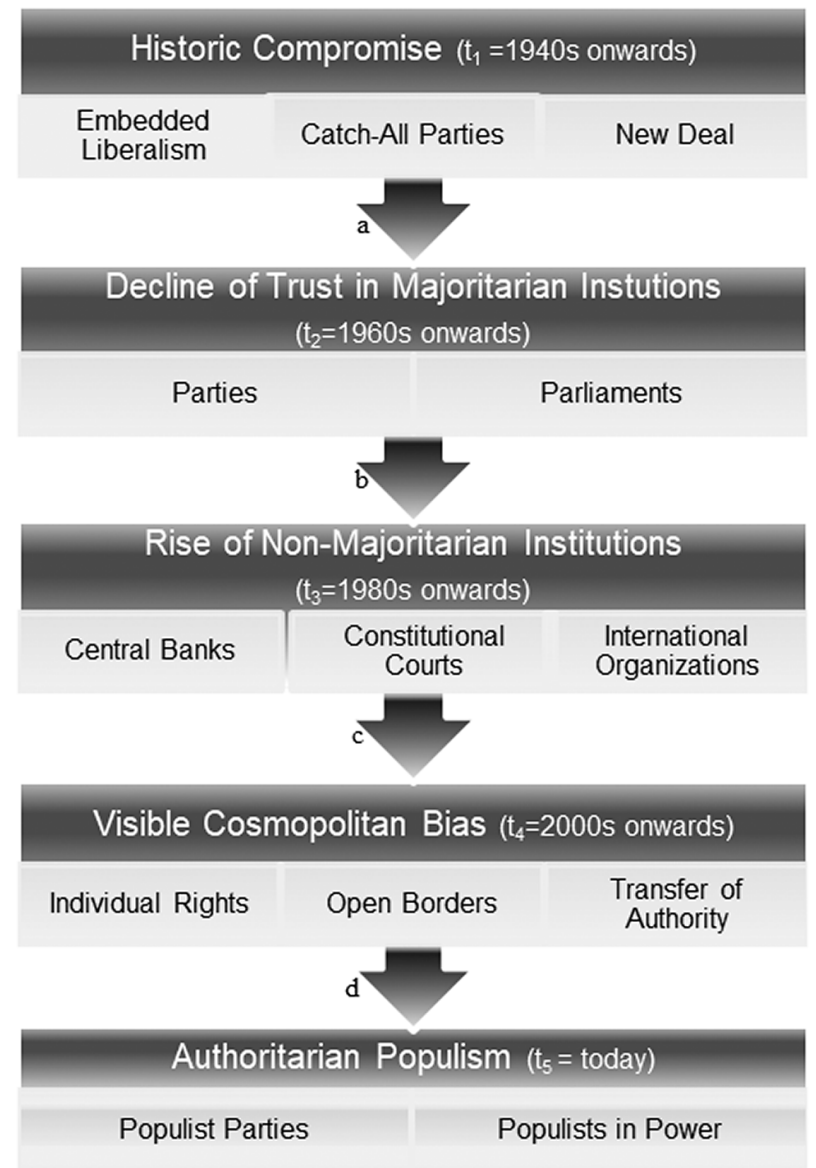

Legend for the Micro-Links: $\mathrm{a}=$ ideological and representational effects of party cartelization; $\mathrm{b}=$ legitimacy- and trust seeking; $\mathrm{c}=$ the inner logic of NMls plus crises; $d=$ perception that the system is not responsive

The political explanation brings together two general developments in modern democracies: the professionalization or cartelization of catch-all parties (Dahl 1965; Giger, Rosset and Bernauer 2012; Gilens and Page 2014) and the observation that NMIs are a major target of contemporary populism (Mounk 2018). It has similarities to an approach that considers the current crisis of democracy due to the rise of technocracy (Bertsou and Pastorella 2017; Canovan 1999; Caramani 2017). The political explanation is, however, different in two respects. First, the primary target of authoritarian populists are not technocrats but NMIs. NMIs, in turn, do not build on a homogenous notion of the will of the people as technocrats implicitly do. Still, they often point to the rights of individuals and minorities with other lifestyles and preferences. Technocrats and authoritarian populists, therefore, are often seen as two related challenges to representative democracies, while NMIs are a necessary part of them. ${ }^{7}$ Second, the political explanation separates the cartelization of parties and the rise of NMIs as two distinct processes instead of throwing them together under the label of technocracy.

The political explanation also differs from the socioeconomic and socio-cultural explanations that dominate the study of the rise of populism. First, the political explanation comes with more historical depth. It captures a process that started long before the rise of inequality and cultural conflicts in consolidated democracies. More importantly, the political explanation does not focus on policies, but politics. In this institutionalist view, it is the political system and not the specific policies that are targeted. At the same time, the political explanation incorporates some of the insights of the dominant explanations. The explanation takes up the widespread perception of unjustified inequality by pointing to the cosmopolitan bias of NMIs and the 
uneven responsiveness of parliaments. Both of these have a socio-economic and socio-cultural meaning. They lead to a perceived privilege of the educated and mobile people with transnational social capital. While the political explanation integrates these aspects, it focuses on the political system and class.

\section{Probing the Explanation}

We derived four propositions from the discussion in the second section. They are brought together in a DAG that captures a sequence of developments connected by generalizable mechanisms. Each of them will now be examined by checking the chronological order of the proposed trends and probing the causal mechanisms. ${ }^{8}$

For this purpose, we pick countries that were electoral democracies at the beginning of the century. As a prerequisite, they should have an open electoral system, a multi-party system, a working parliament, and some separation of powers to distinguish between MIs and NMIs, at least for some time. This is operationalized by an index of what would be an overall score of 80 or more in today's Freedom House Index in early 2000 ("Democracies" in 2001). Also, the selected countries must be included in most of the WVS waves to allow for a comparison of data about trust in institutions that goes back at least to the 1980s. We ended up with sixteen countries that include consolidated democracies with an established separation of powers and without major institutional changes at least since World War II. The sample also includes some more precarious democracies that experienced instability since World War II and for which the political explanation seems, at first sight, less applicable. These hard cases include countries that are currently governed by authoritarian populists that fell by now below the 80 threshold of the Freedom House Index, such as Turkey, or were dictatorships for some time after World War II, such as Chile. The sixteen selected countries that fulfill the conditions regarding data availability do not contain an obvious bias in favor of the explanatory model.? In this way, we present a plausibility probe of the model. It is no rigorous test of the causalities suggested in the model.

According to Proposition 1 (P1), the decline of trust in the MIs of electoral democracies started during the heyday of catch-all parties between the 1950s and 1970s. This is the period when social-democratic parties received the highest vote share (Benedetto, Hix, and Mastrorocco 2020, 930) and when the party fragmentation in the sixteen countries was largely very low. ${ }^{10}$ In most of the sixteen countries, the vote share of catch-all parties declined only slightly in the late 1970s, and some even reached a second peak in the mid-1980s or later. Against this background, we would expect a decline of trust in parties and parliaments from the 1960s on.

Unfortunately, most of the measures that compare trust in different institutions in various countries lack the historical depth needed to answer this question. Colin Hay (2007), however, has gathered and analyzed some data that go back far enough. The percentage of people in the United States saying that politicians "care what people think" plunges from over $70 \%$ in 1958 to slightly more than 30\% in 2004 (Hay 2007, 28; see also Norris 2011, 65). This is no American exceptionalism. Hay $(2007,30)$ also presents survey data from three consolidated democracies - the United States, Sweden, and Francethat is based on a similar question: "Do politicians care?" The three curves develop very much in parallel and on the same level.

For the sixteen countries selected for this study, WVS data is available for most of the six waves from the early 1980s. ${ }^{11}$ To elaborate P1 on this basis, we focus on the question about confidence in parliament. For reasons of simplicity, we compound the values of "a great deal" and "quite a lot," which in the survey is contrasted with "not very much" and "not at all," as well as "don't know" (usually clearly below 10\%). The overall trend is in line with the expectation in P1. We can observe a permanently decreasing amount of trust in MIs, in spite of significant variations between countries and outliers inherent in this indicator that is often affected by specific events. Only recently, with the revival of majoritarian politics - the final step in the sequence-this trend has been reversed (see also the discussion of Proposition 4). Given the relatively low levels of support already in the early 1980s, it also seems plausible to assume that the decline in confidence started in generalnot only in the United States and in Sweden-earlier. While we see some outliers (especially in the 1999-2004 wave), the values for most countries in the most recent two waves are clearly below the numbers for the first two waves. For Poland, a country that became democratic only in the early 1990 s, the values decreased from $55.2 \%$ in wave two, to $30.1 \%$ in wave three, to about $11.0 \%$ in waves five and six. It seems that this new democracy has replicated the full path in only twenty years. The significance of the data becomes even more apparent when compared with other countries of the WVS, which were not democracies in 2001 (refer to online appendix 2).

Can the decline indeed be ascribed to ideological and representational effects of party cartelization? On one hand, P1 is based on the expectation that programmatic difference between the catch-all parties in the socioeconomic realm declines in parallel to trust. Wolfgang Merkel $(2016$, 67) summarizes the analysis of manifesto data: "The programmatic differences on classical socioeconomic (such as the role of the state, market regulation, nationalization, social welfare, fiscal policies) have virtually disappeared during the last decades." For the consolidated democracies, this growing similarity of catch-all parties had already started in the late 1940s and was particularly sharp in the 1960s up to 1980 (with a slight recovery in the early 1970s; Przeworski 2019, 95, figure 5.7). 
On the other hand, the decline of trust is expected to be due to a growing selectivity of representation in parliaments. Assuredly, parliaments have never been a true reflection of the population. In most countries, men have always been over-represented, members of parliament are older than the population average, and people with a history of migration have almost always been severely underrepresented. While the representativeness of parliaments has moderately improved on these counts, the representation of workers or ordinary employees in the parliaments of wealthy democracies declined further. The "upper-class accent" of the parliament (Schattschneider 1960) has been transformed into a "diploma parliament" (Bovens and Wille 2017). The share of workers in socialdemocratic parties and entrepreneurs in liberalconservative parties declined (Elsässer, Hence, and Schäfer 2018).

There are two important alternative explanations for the decline of trust in parties and parliaments. One points to the decline of industrial workers and the associated decline in union organization. This political economy explanation may be useful to explain the decline in electoral support for social-democratic parties that started in the 1970 s (Benedetto, Hix, and Mastrorocco 2020, 950). However, it cannot explain the erosion of trust in parties in general that had already started a decade earlier. Namely, the share of the industrial sector fell in Western Europe only in about 1970 (Benedetto, Hix, and Mastrorocco 2020, 932), the union density reached its peak in the OECD world in 1980, and fell only afterwards (Armingeon et al. 2020; Przeworski 2019, 112). Moreover, we observe a loss in trust in parties and parliaments as a whole that cannot be reduced to declining support of union-organized socialdemocratic voters.

The more relevant competing explanation takes voters' education and informational levels into account, reducing the dependency on parties and increased party-independent judgements. This explanation comes in several versions (see, above all, Norris 2011; Inglehart and Welzel 2005). Better educated and informed voters can undoubtedly contribute to party dealignment and party fragmentation. Still, it is less clear why better education should lead to declining trust in parties and parliaments in general, especially given that better-educated and informed people typically have more trust. It requires changes in the institutional practice- such as party cartelization and its effects-in the first place (see also Neblo et al. 2010).

In sum, the data is roughly in line with the causal mechanisms outlined in the model. Those countries with long-existing and strong catch-all parties (which reached $90 \%$ of the vote share already in the early 1960 s and stayed on a stable level for two decades), such as Australia, Germany, Norway, Sweden, and the United States, have very low trust values in the WVS wave 2005-2009 (see figure 2).
Proposition 2 (P2) states descriptively that the decline of trust in MIs leads to a rise of NMIs in the 1980 s and 1990s. In general, the growing relevance of NMIs has been demonstrated in several studies. First, many domestic legislatures in the world haveespecially from the 1990s on-decided to give supreme courts more rights and competences. Ran Hirschl sums up this development in the opening sentence of his critical study, Towards Juristocracy: "Around the globe, in more than eighty countries and several transnational entities constitutional reform has transferred an unprecedented amount of power from representative institutions to judiciaries" (Hirschl 2004, 1). Second, according to Rapaport, Levi-Faur and Miodownik (2009), no fewer than eighty-four countries passed legislation to enhance the formal autonomy of central banks between 1990 and 2008 (see also Cukierman 2008). Moreover, Jordana, Fernández-i-Marín, and Bianculli (2018) have shown that regulatory agencies independently exercising authority have emerged and diffused, especially from the 1980s. It is, however, not only NMIs within democracies but also international institutions that disempower national MIs like parliaments and parties. Two datasets regarding international authority have shown a significant increase in international authority over time (Hooghe, Lenz, and Marks 2019; Zürn, Tokhi, and Binder, forthcoming). Both point to an exceptional rise in the 1990s.

To explore P2 more systematically regarding the sixteen countries under question, data about non-regulatory agencies is fused with data about the rise of international authority. The ensuing NMI index takes into account NMI development on the national level and beyond. Jordana, Fernández-i-Marín, and Bianculli (2018) provide cross-country data about the number of sectors with at least one regulatory agency. They observe agencies in two overlapping categories of attributes: countries and sectors. They chose seventeen sectors to cover a wide range of policy areas where regulation is relevant, including competition, electricity, environment, financial services, food security, gas, health services, insurance, nuclear safety, pensions, pharmaceutics, postal services, securities and exchange, telecommunications, water, and work safety. They also included central banking, but not constitutional courts. The database comprises 799 regulatory agencies in place in any of the seventeen policy sectors selected in 115 countries, which were operative on December 31, 2010. ${ }^{12}$

The International Authority Database (IAD) has measured international authority by an analysis of thirty-four IOs looking at all the treaties, their amendments, and procedural protocols, starting from $1948 .{ }^{13}$ Authority is measured as the product of autonomy of the institution and their bindingness of instruments and their functional scope. Scope refers to the number of issues regulated by the IO. Autonomy points to the extent to which decisions can 


\section{Figure 2}

\section{Decline of trust in Mls in sixteen electoral democracies}

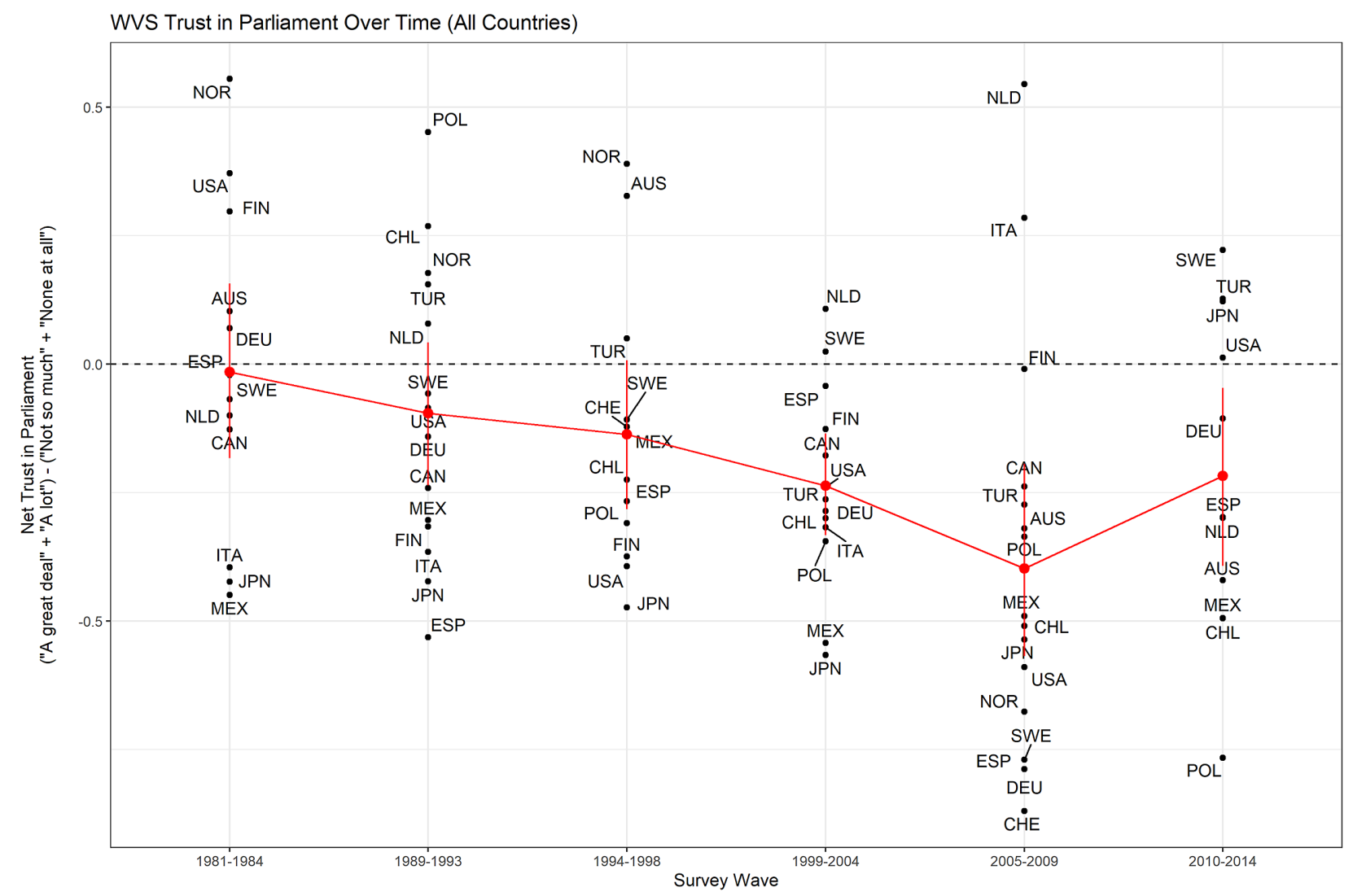

Source: Inglehart et al. 2014

be made without the consensus of all members. Bindingness is measured in terms of the level of obligation for the members. ${ }^{14}$

The datasets about regulatory agencies and international authority can be combined into one NMI index for electoral democracies. For this purpose, we standardized the country-level values for the sixteen states under question between zero and one for both national and international NMIs. The resulting NMI index looks breathtaking. Accordingly, the importance of NMIs has-fully in line with P 2-more than doubled between the late 1970s and the early 2000s. This finding also implies that the power of MIs has been significantly reduced in the last twenty-five years. ${ }^{15}$

Separating national NMIs and NMIs beyond the nation-state brings additional observations to the fore, as figure 3 shows. First, both types of NMIs rise in all sixteen countries in question, without exception. Second, the relative importance of NMIs beyond the nation-state is dependent upon membership in the EU, especially the Eurozone. In the Americas, as well as in Australia and
Japan, national regulatory agencies are more relevant than IOs-except for Canada. Third and most importantly, the rise of NMIs is most substantial in the period 1980-2000, and comparatively dramatic after 1990 . These observations are in line with $\mathrm{P} 2$.

The reason for the rise of NMIs as a whole has been little explored so far. In the specific case of supreme courts, Hirschl (2004) considers it as the product of a strategic interplay among threatened political elites, influential economic stakeholders, and judicial leaders. Research on central banks emphasizes the growing importance of price stability in a globalized economy as a cause (Cukierman 2008), which then has led to a global diffusion (Rapaport, Levi-Faur, and Miodownik 2009). The rise of international institutions is mostly considered as the outcome of growing interdependence and a self-reinforcing liberal international order (Lake, Martin, and Risse 2021; Ruggie 1994; Zürn 2018). Together, these explanations point to a demand for institutions that can carry out policies leading out of stagflation, and are in line with the push towards globalization. They are thus compatible with the two 


\section{Figure 3}

\section{National and international NMIs per country}
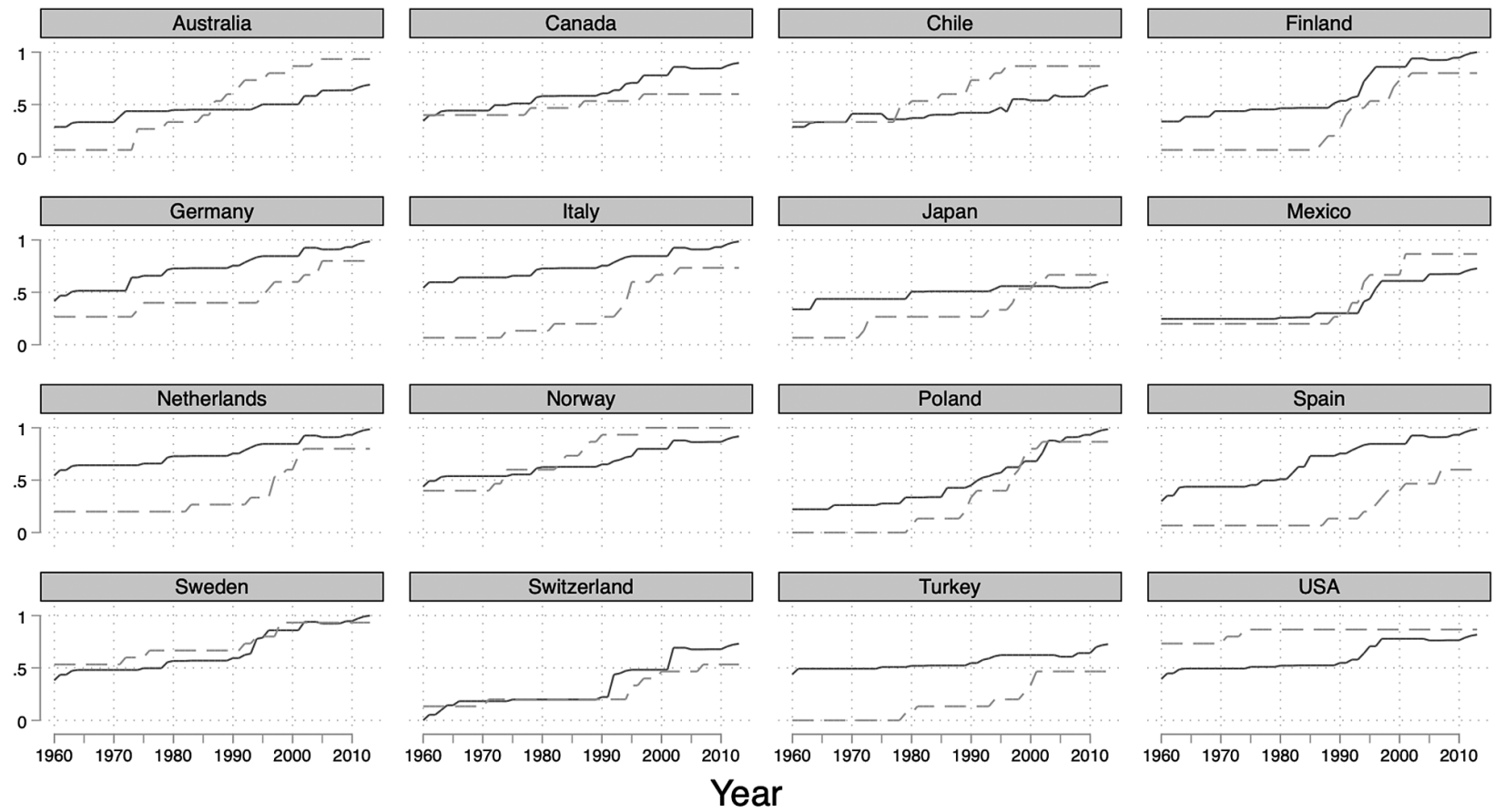

\section{Graphs by country}

\section{Year}

- IO Authority $\quad--$ Regulatory Agencies

causal mechanisms associated with P2, i.e., legitimacy seeking for unpopular policies and trust building for international investors.

There is one account that can be seen as an alternative explanation for the general rise of NMIs. In this view, the rise of NMIs is a function of the victory of neo-liberalism. It is true that central banks and (some) international institutions play a very important role in the attempt to de-politicize the regulators and guarantors of open markets (e.g., Slobodian 2018). This is captured in the model as the signaling function in the competition for global capital. There are, however, separate drivers that started before the rise of neo-liberalism. The general trend of the rise of NMIs indeed began in the 1970s, before the rise of neoliberalism. Besides, the general trend includes courts as well as market-correcting instead of only market-making international institutions such as the United Nations Environment Programme or the International Coffee Organization (Zürn 2002). Neither of them is an agent of neo-liberalism.

Figure 4 illustrates that the rise of NMIs runs very much in parallel with the decline of trust in MIs, and it started before the age of neo-liberalism. ${ }^{16}$ The observations are in line with P2 and the causal mechanisms identified in the model.
Proposition 3 (P3) contains the statement that NMIs hold positions that are leaning more to the cosmopolitan pole of the new cleavage than MIs. This tendency became especially evident in the late 2000s when NMIs had reached the peak of their power and recurring crises brought them to the fore. We use claims-making data about the positioning of different types of actors on a relevant set of issues to elaborate on this proposition. ${ }^{17}$

The method of claims analysis allows to focus on the positions actors take in a specific issue area (Koopmans and Statham 1999). To investigate actors' positions on issues of globalization, we use a dataset consisting of 11,810 claims expressed either in public media in Germany, Poland, Mexico, Turkey, and the United States, or the European Parliament and the United Nations General Assembly. For our analysis, we used two variables. First, the issue position denotes an actor's general position towards open borders (integration) or closed borders (demarcation) as well as demands for the further transfer of authority (integrate) or demands for political nationalization (demarcate). Issue position then can take four values: "integrate" (1), "keep integrated" (2), "demarcate" (3), and "keep demarcated" (4). ${ }^{18}$ The "average position" on these two issues is the dependent variable. Second, actors were distinguished according to the function they 


\section{Figure 4}

\section{NMI index and trust in Mls}
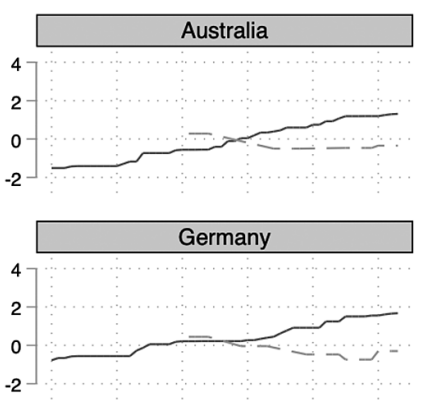

Netherlands
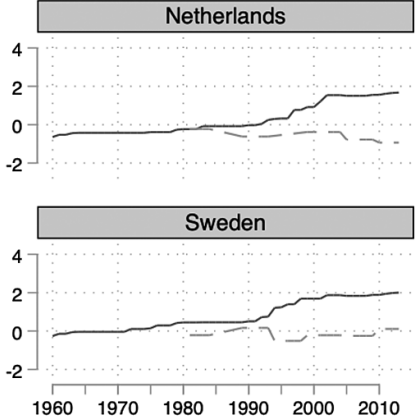

Graphs by country
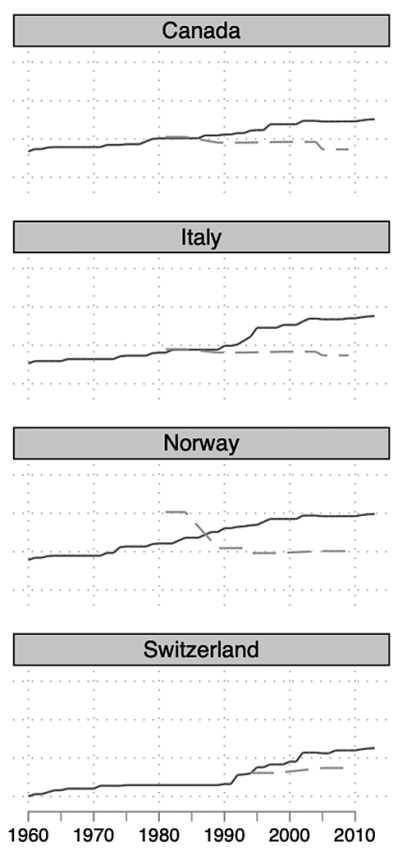
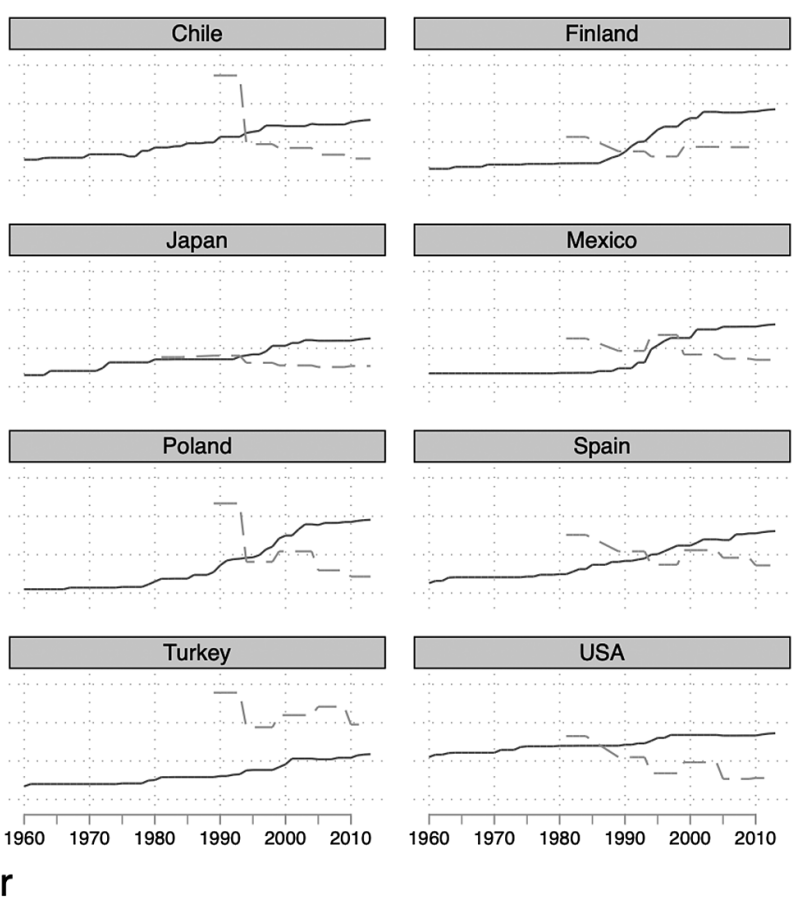

\section{Year}

Sum NMI $\quad-\quad-$ Great Trust in Parliaments

play in the different political systems: the executive (e.g., the United Nations Secretary-General, national governments, the EU Council of Ministers); the legislative (e.g., the European Parliament, national parliaments, city councils); the judiciary (e.g., the European Court of Human Rights, the German Constitutional Court); experts; and other non-executive actors performing on the level of IOs. ${ }^{19}$

The results are unambiguous. Legislators-as the archetype of a majoritarian actor-are close to the middle position (2.5) with an average of around 2.1. On the contrary, all the claims made by representatives of NMIs lean much more towards the liberal cosmopolitan pole (1 is maximal openness and integration). In agreement with the theoretical reasoning, the positions for governments are closer to non-majoritarian actors than to the legislatures, since they are considered as part and parcel of the cosmopolitan elite- unless they are controlled by authoritarian populists. More concretely, representatives of IOs are most cosmopolitan with an average value of 1.5, followed by executives, experts, and the judiciary, all of them with an average between 1.6 and 1.7. All the differences to the legislative baseline are significant (see figure 5). ${ }^{20}$

This cosmopolitan bias is partly inscribed in the purpose of NMIs. Moreover, the argument states that the visibility of the importance of NMIs grows over time, especially during crisis. Crises function, in that respect, like a magnifying glass that enlarges and thus makes it possible to see things that one cannot see otherwise. In this sense, especially the financial crisis and migration as a consequence of the crisis in Syria have made the changed political processes in democracies more visible. In all these crises, essential decisions have no longer been made by elected parliaments, but by other political institutions. The crises brought the executive branch and experts and NMIs into the limelight-Mario Draghi and all the chief virologists during the COVID-19 crisis stand for exactly that.

Proposition 4 ( $\mathrm{P} 4)$ points to the revival of the silent majority in favor of majoritarianism and the rise of authoritarian populist parties. Taking into account a time lag for the realization, the process can be expected to start in the 1990s - a decade after the stark growth rates for NMIs. Figure 6 shows that the rise of authoritarian populist parties in national elections of the selected countries started in the 1990s, it accelerated in the 2000s, and has grown especially strong since 2005 . The difference between now and the early 1990s is statistically significant, and it cannot solely be attributed to the strong rise in countries like Switzerland, Poland, and Italy. The rise of authoritarian populist parties is also shown in studies that 


\section{Figure 5}

\section{The cosmopolitan bias of NMls}

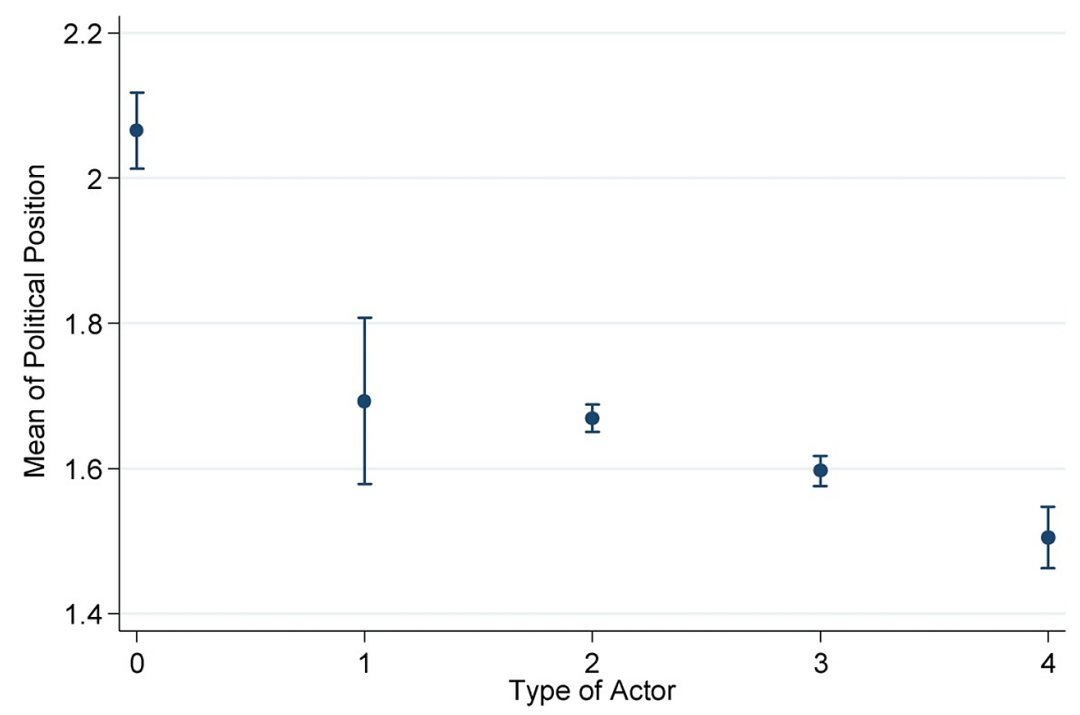

Means of Political Positions of Actors. Legend: 0 = legislative; 1 = judiciary; 2 =experts; 3 =government /executive; 4 =non-executive IOs Political position ranges from 1 (cosmopolitan) to 4 (communitarian). 95\% confidence intervals included.

include more than the sixteen countries (see Norris and Inglehart 2019; Timbro 2019). In parallel, there is a recovery of trust values in parliaments from the mid-2000s (see figure 2). While the declining trust in MIs could be compensated by high trust in NMIs for a long time, the increased visibility of their cosmopolitan bias serves as a gamechanger. Especially from 2005 on, we see a slight recovery in the trust of MIs, a strongly growing dissatisfaction with democracy as a whole (see Foa et al. 2020), and a rise of authoritarian populist parties.

The historical-institutionalist explanation focuses on features of political systems. There are a number of alternative explanations that focus instead on policies. First of all, many commentators point to the austerity policies during the financial crisis and Chancellor Merkel's open border policy in 2015 as the driver of authoritarian populism (see, e.g., Foster and Frieden 2017; Kriesi 2020). While these decisions have certainly accelerated the rise of authoritarian populists, such reasoning underestimates how long the trend has already existed. Other explanations see the rise of authoritarian populism as a response to long-standing and one-sided policies in the socio-economic and socio-cultural realm. However, the socio-structural features of the voters of authoritarian populist parties are not strictly structured across income and class division, but they rather emphasize the difference between the communitarian somewhere and the cosmopolitan nowhere (Goodhart 2017). This may explain why the socio-cultural explanation displays fairly stronger effects for their variables on the micro-level (see, e.g.,
Norris and Inglehart 2019). In any case, both of the dominant explanations can account only for a relatively limited explanation (Przeworski 2019, 131). According to the political account, the mobilization of the unevenness and differences is targeted against the system and not against policies; against the political class and not against economic elites; against the internationalists and not the owners of national champions. Respectively, the composition of supporters is mixed and based on the intermediate perception of a closed and non-responsive political system dominated by NMIs.

Is there positive evidence for the postulated causal mechanism as well? Figure 7 shows the development of the rise of authoritarian populist parties and the rise of NMIs. When both lines move, they do so in parallel, and both start to grow before the financial crisis, the salience of immigration debates, and the revival of inequality in consolidated countries. This can be seen very clearly in cases such as Finland, the Netherlands, Norway, and Poland. The Pearson correlation coefficient between NMI and vote share of populist parties is .227.

Figure 7 even underestimates the association to some extent since the vote share of authoritarian populist parties accelerates after 2014, as shown in figure 6. This trend is especially relevant for some of the cases-figure 7 shows a flat vote share line until 2013. The authoritarian populist capturing of the mainstream Republican Party by Donald Trump in the United States that took place in 2016 is the most critical case. The rise of Vox in Spain took place only recently, thus not reflected in figure 7. Moreover, some 


\section{Figure 6}

\section{The rise of authoritarian populist parties in sixteen electoral democracies}

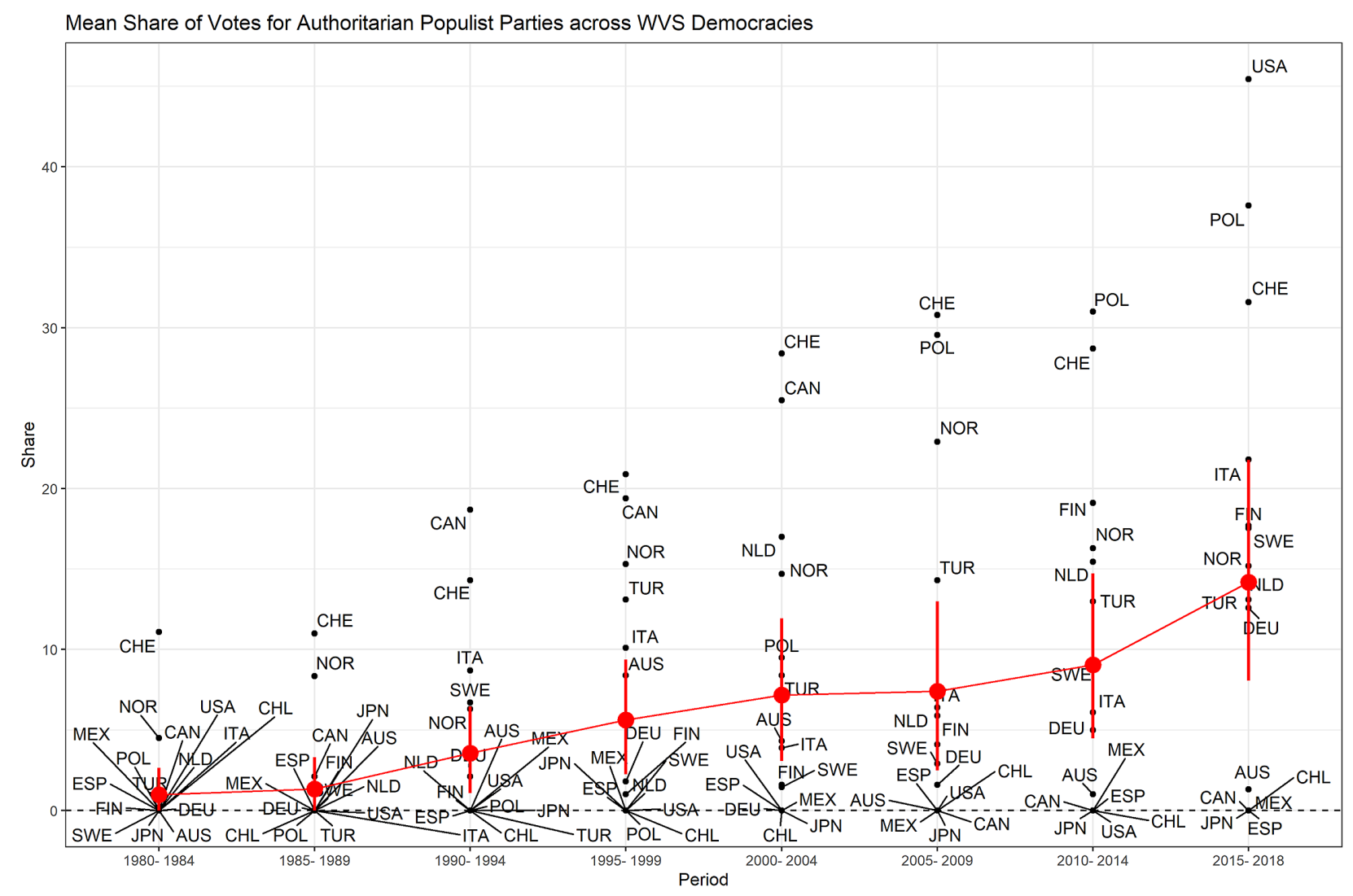

Note: The selection of authoritarian populist parties in the sixteen countries is based on the modified list provided by Norris and Inglehart (2019, 473-475). They combine seven questions from the Chapel Hill Expert Survey (cf. Bakker et al. 2015) to locate parties on the liberal versus authoritarian axis, and two questions to capture how populist they are. This procedure comes close to our understanding of authoritarian populism as developed in section one. For populist parties without further categorization, we based the selection on the list provided by Norris $(2005,55 ; 2019,28-34)$ and secondary literature.

Sources: Norris and Inglehart 2019; Norris 2005, 2020

countries have no or little rise of authoritarian populist parties because a former mainstream party incorporates some authoritarian populist elements into their programs, such as Scott Morrison in Australia or Enrique Peña Nieto in Mexico.

Moreover, the self-description of authoritarian populists points to politics instead of policies. They often complain above all about the political system. In Germany, for example, the Alternative for Germany (Alternative für Deutschland, AfD) wants to overcome the "filthy red-green system." They talk about "system parties" and the "political class." This is the major target of their political campaign as indicated in the political program (AfD 2017). Regarding specific policies and measures, few demands qualify them as outsiders. Certainly, the call for strengthening the external borders is particularly loud but not so specific in the current political landscape. In the socio-cultural field, the commitment to the traditional family as a model is rarely found in this openness, as is the demand for a guiding culture instead of multiculturalism. However, neither of them is exceptional as such. In the socio-economic realm, almost nothing falls outside the framework of what we know from the so-called "system parties": the minimum wage to be maintained, bureaucracy to be reduced, the social market economy to be strengthened, and other objectives that are known from the programs of other parties.

This programmatic orientation of the authoritarian populist parties is successful because it reflects the attitudes of many people. A clear majority is content with economic living conditions and progressive gender policies, but responds negatively to the question "Do you think that elected officials in your country are interested in what people like you think?" 21 Consequently, European Social 


\section{Figure 7}

Rise of NMIs and authoritarian populist parties
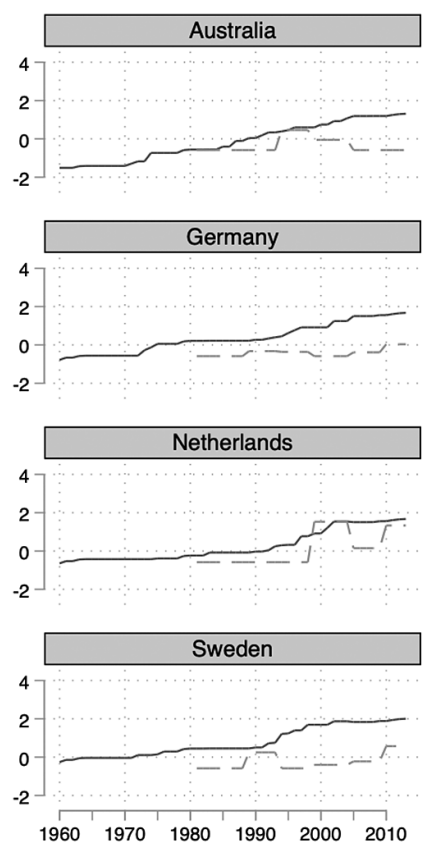

Graphs by country
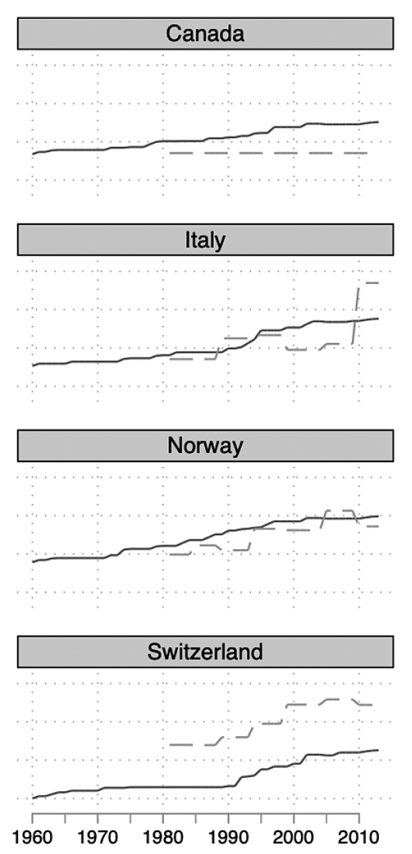
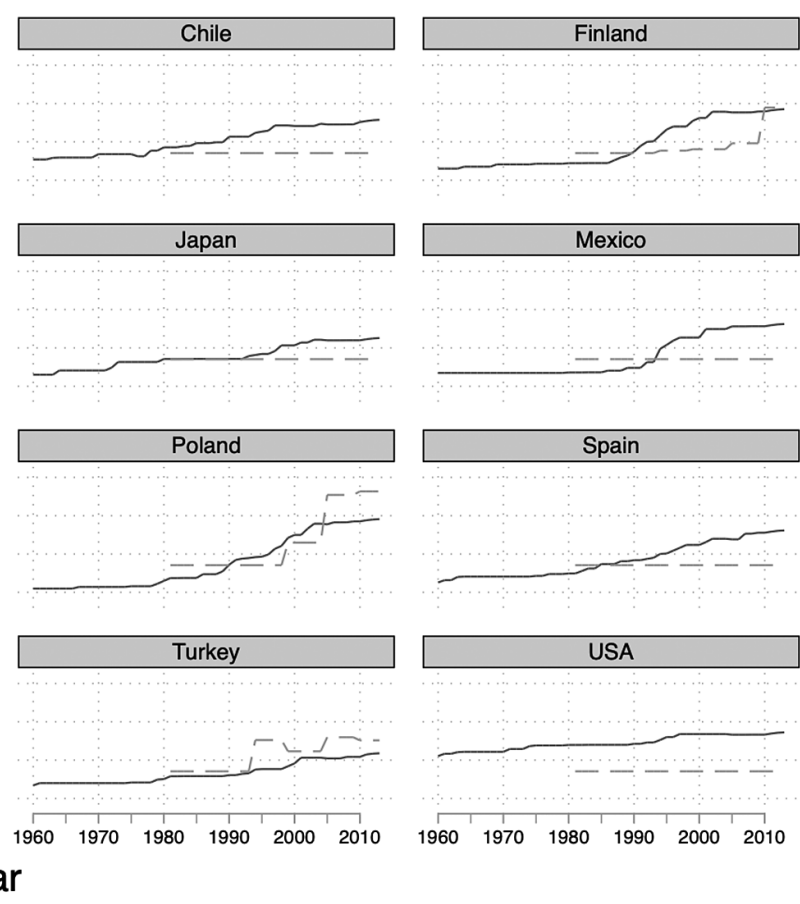
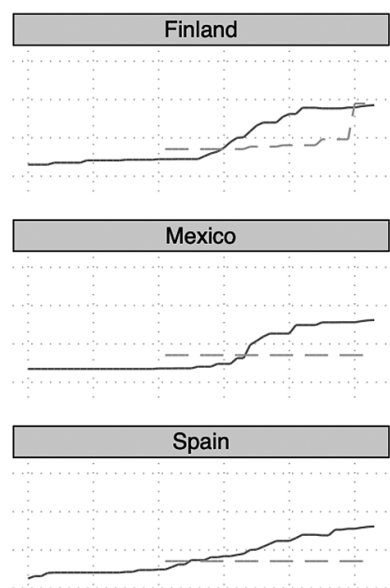

$\begin{array}{llllll}960 & 1970 & 1980 & 1990 & 2000 & 2010\end{array}$

\section{Year}

- NMI -- Vote Share

Survey (ESS) data shows a close connection between the perception of the openness or representativeness of political systems and voting behavior (Schäfer and Zürn 2021, ch. 3). ${ }^{22}$ The lower the perception of the influenceability of decisions and the possibility of having a say, the higher the share of votes for populist parties.

Summing up, all the descriptive propositions derived from the causal mechanism receive empirical support. The timing and the correlations are matching the sequence spelled out in the theoretical narrative. The decline in confidence in MIs started after catch-all parties took over and was followed by the rise of NMIs. The growth of authoritarian populist parties in electoral democracies accelerated when the cosmopolitan bias of these NMIs became apparent. Furthermore, the analysis of the causal mechanisms connecting the nodes of the model based on secondary literature increases the plausibility of the model.

\section{Conclusion}

The rise of authoritarian populism in consolidated democracies has been produced by a reactive sequence. It is the taming of the old class cleavage and the ensuing relative shift between MIs and NMIs that leads-against the background of globalization - to the new cleavage, with authoritarian populists taking one side and liberal cosmopolitans - including large parts of the elites-the other. Within this context, the appeal to the silent majority becomes highly attractive to a significant share of the population in both consolidated and precarious democracies.

Authoritarian populists position themselves against the cosmopolitan bias of NMIs. It captures a significant element of the authoritarian narrative that cannot be reduced to the structurally pre-determined juxtaposition of winners and losers of globalization. Those who advocate closed borders, national sovereignty, and the validity of the majority culture consider themselves as the silent majority that is put aside by the liberal cosmopolitan elites in "socalled democracies." They feel that they have no say in the public discourse and therefore portray mainstream media as biased towards cosmopolitanism presenting fake news. They consider themselves as suppressed or at least forgotten by cosmopolitan experts controlling NMIs and the media. Authoritarian parties make silent majorities vocal. They target both cosmopolitan policies and the polities that produce them. The targeting of NMIs promises to be especially successful after crises, when their strength and cosmopolitan bias of their policies are prominent. The European debt crisis is paradigmatic in that respect. The political explanation thus incorporates elements of 
the economic and cultural explanation. However, the target is the lock-in of certain policies-not the policies themselves.

While it is true that authoritarian populists target the cosmopolitan bias of NMIs, there is little indication that their policies necessarily benefit the poor, reduce inequality, and work against the super-rich. The 2019 tax reform by the Trump administration and the considerations about the reduction of corporate taxes after Brexit suggest the opposite. Authoritarian populist parties are anti-liberal as well as anti-pluralist, thus jeopardizing democratic political systems. Moreover, they need to play the national, anti-internationalist card to keep their enemies alive.

\section{Supplementary Materials}

Appendix 1. Trust into Different Branches of Governance Appendix 2. WVS Trust in Parliament Over Time (all countries)

Appendix 3. The Rise of NMIs in 16 Electoral Democracies (NMI Index)

To view supplementary material for this article, please visit http://doi.org/10.1017/S1537592721001043.

\section{Acknowledgements}

Earlier versions of this paper were presented at the workshop "Beyond Representative Democracy? Design and Legitimacy of Non-Majoritarian Institutions" at the Global Governance seminar series at the WZB Berlin Social Science Center, at a workshop on the "Tide of Populism" at Freie Universität Berlin, and at the seminar series at ARENA in Oslo. I want to thank all the participants for their extremely useful comments, especially Tanja Börzel, Erik Oddvar Eriksen, Anna Geis, Johannes Gerschewski, Cristóbal Rovira Kaltwasser, Christian Kreuder-Sonnen, Claudia Landwehr, Maximillian Lobbes, Rebecca Majewski, Álvaro Morcillo Laiz, Christoph Möllers, Johan Olsen, Christian Rauh, Armin Schäfer, and Jonas Tallberg. In addition, the author is very grateful to the three reviewers of Perspective on Politics for their extremely helpful and constructive comments. Very special thanks go to Johannes Scherzinger and Alexandros Tokhi for their invaluable support in getting and analyzing the data. Lisa Maaßen and Barçın Ulusşı provided most helpful editorial support.

\section{Notes}

1 Richard Nixon invoked the term "the great silent majority of my fellow Americans" in his television speech "Address to the Nation on the War on Vietnam" on November 3, 1969 (http://watergate. info/1969/11/03/nixons-silent-majority-speech. html).

2 Remarkably, France, the Netherlands, and Austria, the three consolidated democracies where authoritarian populists celebrated their first successes, have a much smaller (if it all) rise of inequality than other consolidated democracies. See, e.g., OECD 2015, 24.

3 In eight out of sixteen selected countries, respondents rank each of the three NMIs (Justice, the EU, and the United Nations) higher than parties, parliaments, and governments. In three additional countries, parties and parliaments have the lowest value of all institutions with governments moving partially into the ranks of NMIs. In four more cases, at least the average confidence in NMIs is higher than the average confidence in MIs. Only Finland and Turkey deviate-to some extent-from this pattern, both still with very low values for parties (refer to refer to online appendix 1).

4 The hypothesized direction of causality is compatible with prevailing theories (institutions change when legitimation problems arise, and globalization has exerted pressure on domestic politics). It is also in line with the observed timing (refer to the third section). This does not exclude feedback effects so that NMIs may have additionally contributed to globalization and the decline of trust in MIs.

5 In the case of international institutions, the cosmopolitan bias is most obvious. On the contrary, national courts may sometimes defend national laws against international laws, however rare. In any case, they defend individual rights against the will of the majority. Even when the supreme court was still an "aristocratic institution," it would check the power of the masses.

6 Supporters of authoritarian populists do not need to understand the whole chain. Each micro-mechanism works independently of each other. When people sense the cosmopolitan bias of the people in Brussels or the coastal elites, they do not need an explanation as to why they have a cosmopolitan bias and why these groups are elites. To become a voter of an authoritarian populist party, it suffices that they dislike them.

7 Bertsou and Pastorella 2017 show that citizens are more inclined to support the technocratic mode of governance when they have weaker democratic attitudes and distrust their politicians and representative institutions. On the contrary, respect for NMIs goes hand in hand with democratic attitudes and trust.

8 See Waldner 2015 and Copestake, Goertz, and Haggard (forthcoming) for examinations of such a methodology.

9 The full list comprises Australia, Canada, Chile, Finland, Germany, Italy, Japan, Mexico, the Netherlands, Norway, Poland, Spain, Sweden, Switzerland, Turkey, and the United States.

10 The party fragmentation was assessed on the basis of party manifesto data. I am thankful to Heiko Giebler for providing the data.

11 The first round of the European Social Survey (ESS) starts only in 2012. The Eurobarometer included 
questions that differentiate trust in parties, parliaments, and executives only from 2015 on; Eurobarometer 83. However, it has raised the question about (dis)satisfaction with democracy in 1977 and 1986.

This data has been recently included in an effort by the Cambridge Centre for the Future of Democracy, integrating and standardizing all survey series that includes this question. In the aggregate, this shows an up-and-down in the satisfaction with democracy but a steep decline from 2005 on. This is in line with the explanatory model that expects a shift of trust within democracies until the early 2000s, and a rise of dissatisfaction with democracy as a whole from then on.

12 "Agencies operating in these sectors were selected according to the following criteria: 1) focus on regulatory tasks, for example, rule supervision, rule enhancement, and rule definition; 2) stable entities created by public legal acts that perform public tasks; 3) organizational units formally separated from larger departmental and ministerial structures or from public bureaucratic frameworks; 4) existence of public servants — whether tenured or not — and budgets under public control; 5) national scope ([excluding] supranational and subnational agencies)"; Jordana, Fernández-i-Marín, and Bianculli 2018, 529.

13 See Zürn, Tokhi, and Binder (forthcoming) for a detailed description of the data.

14 The IAD collected data for thirty-four IOs (and more than 230 bodies) across seven policy functions derived from the policy cycle. These are 1) agenda setting, 2) rule making, 3) monitoring, 4) norm interpretation, 5) enforcement of decisions, 6) evaluation, and 7) knowledge generation, see also Bradley and Kelley 2008. These functions focus on different activities of IOs reflecting the notion that authority is exercised when making decisions or interpretations. This understanding of authority includes international courts. Founding treaties and all the changes made to them over time were used to assess formal authority. The coding instrument followed a three-step logic. First, does the IO have the right to authorize any of these functions? Second, if so, who carries out the function (a body of the IO, member state, other actor, including non-state actors)? Third, how is the function carried out and how "authoritative" is it?

15 Refer to online appendix 3.

16 Both variables have been $\mathrm{z}$-standardized to better compare their respective and joint trends. The Pearson's correlation coefficient between "Great Deal of Trust in Parliaments" and NMIs is -0.386 .

17 See de Wilde, Koopmans, and Zürn 2014 for a detailed presentation of the data in the online technical report including sampling of documents, coding instructions, the construction and distribution of variables, and intercoder reliability tests. The data is available for only five of our sixteen countries.

18 See de Wilde, Koopmans, and Zürn 2014 for the operationalization of these variables.

19 The unitizing reliability correlation is 0.88 .

20 Also see de Wilde et al. 2019 or other analyses of the data that point to similar results

21 See Jakob Poushter's 2019 article titled "10 key takeaways about public opinion in Europe 30 years after the fall of communism": https://www.pewresearch. org/fact-tank/2019/10/15/key-takeaways-publicopinion-europe-30-years-after-fall-of-communism/.

22 This is based on two questions: 1) To what extent does the political system give people like you the opportunity to influence politics? 2) To what extent does the political system give people like you a say in what the government does?

\section{References}

Ackerman, Bruce. 2000. "The New Separation of Powers." Harvard Law Review 113(3): 633-725.

AfD. 2017. Programm für Deutschland. Wahlprogramm der Alternative für Deutschland für die Wahl zum Deutschen Bundestag am 24. September 2017 (https://cdn.afd.tools/wp-content/uploads/ sites/111/2017/06/2017-06-01_AfD-

Bundestagswahlprogramm_Onlinefassung.pdf).

Armingeon, Klaus, Virginia Wenger, Fiona Wiedemeier, Christian Isler, Laura Knöpfel, David Weisstanner, and Sarah Engler. 2020. Comparative Political Data Set 1960-2018. Zurich: Institute of Political Science, University of Zurich.

Bakker, Ryan, Catherine de Vries, Erica Edwards, Liesbet Hooghe, Seth Jolly, Gary Marks, Jonathan Polk, Jan Rovny, Marco Steenbergen, and Milada Anna Vachudova. 2015. "Measuring party positions in Europe: The Chapel Hill expert survey trend file, 1999-2010." Party Politics 21(1): 143-52.

Bateman, David A., and Dawn Langan Teele. 2020. "A Developmental Approach to Historical Causal Inference." Public Choice 185(3): 253-79.

Benedetto, Giacomo, Simon Hix, and Nicola Mastrorocco. 2020. "The Rise and Fall of Social Democracy, 1918-2017." American Political Science Review 114(3): 928-39.

Bergman, Torbjörn, and Kaare Strøm. 2011. The Madisonian Turn: Political Parties and Parliamentary Democracy in Nordic Europe. Ann Arbor: University of Michigan Press.

Bertsou, Eri, and Guilia Pastorella. 2017. "Technocratic Attitudes: A Citizen's Perspective of Expert DecisionMaking." Western European Politics 40(2): 430-58. 
Bovens, Mark, and Anchrit Wille. 2017. Diploma Democracy: The Rise of Political Meritocracy. Oxford: Oxford University Press.

Bradley, Curtis A., and Judith Kelley. 2008. "The Concept of International Delegation." Law and Contemporary Problems 71(1): 1-36.

Broz, Lawrence J., Jeffrey A. Frieden, and Stephen Weymouth. 2021. "Populism in Place: The Economic Geography of the Globalization Backlash."

International Organization 75(2). doi:10.1017/ S0020818320000314.

Bunge, Mario. 1997. "Mechanism and Explanation." Philosophy of the Social Sciences 27(4): 410-65.

Büthe, Tim. 2002. "Taking Temporality Seriously: Modeling History and the Use of Narratives as Evidence." American Political Science Review 96(3): 481-93.

Canovan, M. 1999. "Trust the People! Populism and the Two Faces of Democracy." Political Studies 47(1): 54-67.

Caramani, Daniele. 2017. "Will vs Reason: The Populist Technocrat Forms of Political Representation and their Critique to Party Government." American Political Science Review 111(1): 54-67.

Cerny, Philip G. 1995. "Globalization and the Changing Logic of Collective Action." International Organization 49(4): 595-625.

Copestake, James, Gary Goertz, and Stephan Haggard. Forthcoming. "The Veil of Ignorance Process Tracing (VoiPT)." Version 7, i.p.

Cukierman, Alex. 2008. "Central Bank Independence and Monetary Policymaking Institutions: Past, Present and Future." European Journal of Political Economy 24(4): 722-36.

Dahl, Robert A. 1965. "Reflections on Opposition in Western Democracies." Government and Opposition 1 (1): 7-24.

- 1989. Democracy and Its Critics. New Haven, CT: Yale University Press.

De Vries, Catherine E., and Sara B. Hobolt. 2020. Political Entrepreneurs: The Rise of Challenger Parties in Europe. Princeton, NJ: Princeton University Press.

De Wilde, Pieter, Ruud Koopmans, Wolfgang Merkel, Oliver Strijbis, and Michael Zürn, eds. 2019. The Struggle Over Borders: Cosmopolitanism and Communitarianism. Cambridge, UK: Cambridge University Press.

De Wilde, Pieter, Ruud Koopmans, and Michael Zürn. 2014. "The Political Sociology of Cosmopolitanism and Communitarianism: Representative Claims Analysis." WZB Discussion Paper SPIV 2014-102.

Downs, Anthony. 1957. An Economic Theory of Democracy. New York: Harper \& Row.

Elsässer, Lea, Svenja Hense, and Armin Schäfer. 2018. "Government of the People, by the Elite, for the Rich:
Unequal Responsiveness in an Unlikely Case.” MPIfG Discussion Paper No. 18/5 (https://www.econstor.eu/ bitstream/10419/180215/1/1025295536.pdf).

Elster, Jon. 1989. Nuts and Bolts for the Social Sciences. Cambridge, UK: Cambridge University Press.

- 1994. "Die Schaffung von Verfassungen: Analyse der allgemeinen Grundlagen." In Zum Begriff der Verfassung. Die Ordnung des Politischen, ed. Ulrich K. Preuß. Frankfurt am Main: Fischer.

Esping-Andersen, Gøsta. 1990. The Three Worlds of Welfare Capitalism. Princeton, NJ: Princeton University Press.

Eurobarometer 83. 2015. "Public Opinion in the European Union.” European Commission (https:// ec.europa.eu/commfrontoffice/publicopinion/ archives/eb/eb83/eb83_first_en.pdf).

Flaherty, Thomas M., and Ronald Rogowski, 2021. "Rising Inequality as a Threat to the Liberal International Order.” International Organization 75(2). doi: $10.1017 /$ S0020818320000648.

Foa, Roberto Stefan, Andrew Klassen, Micheal Slade, Alex Rand, and Rosie Collins. 2020. The Global Satisfaction with Democracy Report 2020. Cambridge, UK: Centre for the Future of Democracy.

Foster, Chase, and Jeffrey A. Frieden. 2017. "Crisis of Trust: Socio-Economic Determinants of Europeans' Confidence in Government." European Union Politics 18(4): 511-35.

Freeden, Michael. 2003. Ideology: A Very Short Introduction. Oxford, UK: Oxford University Press.

Fukuyama, Francis. 2018. Identity: The Demand for Dignity and the Politics of Resentment. New York: Farrar, Straus, and Giroux.

Giger, Natalie, Jan Rosset, and Julian Bernauer. 2012. "The Poor Political Representation of the Poor in a Comparative Perspective." Representation 48(1): 47-61.

Gilens, Martin, and Benjamin I. Page. 2014. "Testing Theories of American Politics: Elites, Interest Groups, and Average Citizens." Perspectives on Politics 12(3): 564-81.

Goertz, Gary. 2017. Multimethod Research, Causal Mechanisms, and Case Studies: An Integrated Approach. Princeton, NJ: Princeton University Press.

Goodhart, David. 2017. The Road to Somewhere: The Populist Revolt and the Future of Politics. Oxford, UK: Oxford University Press.

Hay, Colin. 2007. Why We Hate Politics. Cambridge, UK: Polity Press.

Hirschl, Ran. 2004. Towards Democracy: The Origins and Consequences of the New Constitutionalism. Cambridge, MA: Harvard University Press.

Hobolt, Sara B. 2016. "The Brexit Vote: A Divided Nation, a Divided Continent." Journal of European Public Policy 23(9): 1259-77. 
Hochschild, Arlie R. 2016. "The Ecstatic Edge of Politics: Sociology and Donald Trump." Contemporary Sociology 45(6): 683-89.

Hooghe, Liesbet, Tobias Lenz, and Gary Marks. 2019. A Theory of International Organization. Oxford, UK: Oxford University Press.

Inglehart, Ronald, and Pippa Norris. 2017. "Trump and the Populist Authoritarian Parties: The Silent Revolution in Reverse." Perspectives on Politics 15(2): 443-54.

Inglehart, Ronald, Christian Haerpfer, Alejandro Moreno, Christian Welzel, Kseniya Kizilova, Jaime Diez-

Medrano, Marta Lagos, Pippa Norris, Eduard Ponarin, and Bi Puranen et al. 2014. World Values Survey: All

Rounds_Country-Pooled Datafile Version. Madrid: JD Systems Institute (https://www.worldvaluessurvey.org/ WVSDocumentationWVL.jsp).

Inglehart, Ronald, and Christian Welzel. 2005. Modernization, Cultural Change, and Democracy: The Human Development Sequence. Cambridge, UK: Cambridge University Press.

Jordana, Jacint, Xavier Fernández-i-Marín, and Andrea C. Bianculli. 2018. "Agency Proliferation and the Globalization of the Regulatory State: Introducing a Data Set on the Institutional Features of Regulatory Agencies." Regulation \& Governance 12(4): 524-40.

Katzenstein, Peter J. 1985. Small States in World Markets. Industrial Policy in Europe. Ithaca, NY: Cornell University Press.

Keohane, Robert O., Stephen Macedo, and Andrew Moravcsik. 2009. "Democracy-Enhancing Multilateralism." International Organization 63(1): $1-31$.

Kirchheimer, Otto. 1965. "Der Wandel des westeuropäischen Parteiensystems.” Politische Vierteljahresschrift 6(1): 20-41.

Koopmans, Ruud, and Paul Statham. 1999. "Political Claims Analysis: Integrating Protest Event and Political Discourse Approaches." Mobilization: An International Quarterly 4(2): 203-21.

Kriesi, Hanspeter. 2014. "The Populist Challenge." Western European Politics 37(2): 361-78.

Kriesi, Hanspeter. 2020. "Backlash Politics against European Integration." British Journal of Political Science and International Relations 22(4): 692-701.

Kriesi, Hanspeter, Edgar Grande, Martin Dolezal, Marc Helbling, Swen Hutter, Dominic Höglinger, and Bruno Wüest, eds. 2012. Political Conflict in Western Europe. Cambridge, UK: Cambridge University Press.

Krisch, Nico. 2010. Beyond Constitutionalism: The Pluralist Structure of Postnational Law. Oxford, UK: Oxford University Press.

Lake, David, Lisa Martin, and Thomas Risse. 2021. "Challenges to the Liberal Order: Reflections on
International Organization." International Organization 75(2). doi:10.1017/S0020818320000636

Lehmbruch, Gerhard. 1977. "Liberal Corporatism and Party Government." Comparative Political Studies 10(1): 91-126.

Levitsky, Steven, and Daniel Ziblatt. 2018. How Democracies Die. New York: Broadway Books.

Lipset, Seymour M., and Stein Rokkan. 1967. "Cleavage Structures, Party Systems and Voter Alignments: An Introduction." In Party Systems and Voter Alignments. Cross-national Perspectives, ed. Seymour M. Lipset and Stein Rokkan, 1-64. New York: Free Press.

Mahoney, J. 2012. "The Logic of Process Tracing Tests in the Social Sciences." Sociological Methods \& Research 41 (4): 570-97.

Mair, Peter. 2005. Popular Democracy and the European Union Polity. EUROGOV. European Governance Papers No. C-05-03 (http://www.connex-network.org/ eurogov/pdf/egp-connex-C-05-03.pdf).

- 2013. Ruling the Void: The Hollowing of Western Democracy. London: Verso.

Manow, Philip. 2018. Die Politische Ökonomie des Populismus. Berlin: Suhrkamp.

Marks, Gary, and Carole J. Wilson. 2000. "The Past in the Present: A Cleavage Theory of Party Response to European Integration." British Journal of Political Science 30(3): 433-59.

Mayntz, Renate. 2004. "Mechanisms in the Analysis of Social Macro-Phenomena." Philosophy of the Social Sciences 34(2): 237-59.

Merkel, Wolfgang. 2016. "The Challenge of Capitalism in Democracy." Zeitschrift für Vergleichende

Politikwissenschaft 10(1): 61-80.

Milanovic, Branko. 2016. Global Inequality: A New Approach for the Age of Globalization. Cambridge, MA: Harvard University Press.

Mounk, Yascha. 2018. The People vs. Democracy: Why Our Freedom Is in Danger and How To Save It. Cambridge, MA: Harvard University Press.

Mudde, Cas. 2004. "The Popular Zeitgeist." Government and Opposition 39(4): 541-63.

Mudde, Cas, and Cristóbal R. Kaltwasser. 2012. Populism in Europe and the Americas: Threat or Corrective for Democracy? Cambridge, UK: Cambridge University Press.

Müller, Jan-Werner. 2011. Contesting Democracy. Political Ideas in Twentieth-Century Europe. New Haven, CT: Yale University Press.

- 2016. Was ist Populismus. Berlin: Suhrkamp.

Neblo, Michael, Kevin M. Esterling, Ryan P. Kennedy, and David M.J. Lazer. 2010. "Who Wants to Deliberate: And Why?" American Political Science Review 104(3): 566-83.

Norris, Pippa. 2005. Radical Right: Voters and Parties in the Electoral Market. New York: Cambridge University Press. 
2011. Democratic Deficit: Critical Citizens Revisited. Cambridge, UK: Cambridge University Press.

_. 2020. "Measuring Populism Worldwide." HKS

Faculty Research Working Paper Series RWP 20 (002).

Cambridge, MA: Harvard University

Norris, Pippa, and Ronald Inglehart. 2019. Cultural Backlash. Trump, Brexit, and Authoritarian Populism. Cambridge, UK: Cambridge University Press.

OECD. 2015. "In It Together: Why Less Inequality Benefits All." Paris: OECD Publishing.

Przeworski, Adam. 2019. Crises of Democracy. Cambridge, UK: Cambridge University Press.

Rapaport, Orit, David Levi-Faur, and Dan Miodownik. 2009. "The Puzzle of the Diffusion of Central-Bank Independence Reforms: Insights from an Agent-Based Simulation.” Policy Studies Journal 37: 695-716.

Rosanvallon, Pierre. 2008. Counter-Democracy: Politics in an Age of Distrust. Trans. Arthur Goldhammer. Cambridge, UK: Cambridge University Press.

Ruggie, John G. 1982. "International Regimes, Transactions, and Change: Embedded Liberalism in the Postwar Economic Order." International Organization 36(2): 379-415.

- 1994. "Trade, Protectionism and the Future of Welfare Capitalism." Journal of International Affairs 48(1): $1-12$.

Schäfer, Armin, and Michael Zürn. 2021. Die demokratische Regression. Frankfurt am Main: Suhrkamp.

Schattschneider, Elmer E. 1960. The Semisovereign People: A Realist's View of Democracy in America. New York: Holt, Rinehart and Winston,

Slobodian, Quinn. 2018. Globalists: The End of Empire and the Birth of Neoliberalism. Cambridge, MA: Harvard University Press.

Stone Sweet, Alec, and Jud Mathews. 2019. Proportionality Balancing and Constitutional Governance: A Comparative and Global Approach. Oxford, UK: Oxford University Press.
Thatcher, Mark, and Alec Stone Sweet. 2002. Theory and Practice of Delegation in Non-Majoritarian Institutions. Faculty Scholarship Series, Paper 74 (http:// digitalcommons.law.yale.edu/fss_papers/74).

Timbro Populism Index. 2019. "Timbro Authoritarian Populism Index 2019” (https//www.populismindex. $\mathrm{com} /$ ).

Urbinati, Nadia. 2019. Me the People. How Populism Transforms Democracy. Cambridge, MA: Harvard University Press.

Waldner, David. 2015. "What Makes Process Tracing Good? Causal Mechanisms, Causal Inference, and the Completeness Standard in Comparative Politics." In Process Tracing in the Social Sciences: From Metaphor to Analytical Tool, ed. Andrew Bennett and Jeffrey Checkel, 126-52. Cambridge, UK: Cambridge University Press.

Weyland, Kurt. 2017. "Populism: A Political-Strategic Approach." In The Oxford Handbook on Populism, ed. Cristóbal R. Kaltwasser, Paul Taggart, Paulina Espejo, and Pierre Ostiguy, 48-73. Oxford, UK: Oxford University Press.

Whittington, Keith E. 2005. "'Interpose Your Friendly Hand': Political Supports for the Exercise of Judicial Review by the United States Supreme Court." American Political Science Review 99(4): 583-96.

Zürn, Michael. 2002. "Societal Denationalization and Positive Governance." In The Global Polity, ed. Morten Ougaard and Richard Higgot, 78-103t. London and New York: Routledge.

- 2018. A Theory of Global Governance: Authority, Legitimacy, and Contestation. Oxford, UK: Oxford University Press.

_ 2019. "Politicization Compared: At National, European, and Global Levels." Journal of European and Public Policy 26(7): 977-95.

Zürn, Michael, Alexandros Tokhi, and Martin Binder. Forthcoming. "The International Authority Database." Global Policy. 